\title{
Influence of hydraulic retention time on heterotrophic biomass in a wastewater moving bed membrane bioreactor treatment plant
}

\author{
J. Martín-Pascual • P. Reboleiro-Rivas • \\ C. López-López · J. González-López • \\ E. Hontoria $\cdot$ J. M. Poyatos
}

Received: 5 December 2012/Revised: 24 April 2013/Accepted: 6 May 2013/Published online: 24 May 2013

(C) Islamic Azad University (IAU) 2013

\begin{abstract}
Wastewater treatment using moving bed membrane bioreactor technology was tested with real urban wastewater at a pilot plant, combining moving bed treatment as a biological process with hybrid biomass (suspended and fixed) and the advantages of a membrane separation system. The evolution of the kinetic constants of the hybrid biomass and organic matter removal were studied in a pilot plant under different operational conditions, by varying hydraulic retention time (HRT), mixed liquor suspended solids (MLSS) and temperature, and considering the attached biomass of the carrier and the dispersed biomass of the flocs to reproduce real treatment conditions. The rates of organic matter removal were $97.73 \pm 0.81 \%$ of biochemical oxygen demand $\left(\mathrm{BOD}_{5}\right)$, $93.44 \pm 2.13 \%$ of chemical oxygen demand (COD), $94.41 \pm 2.26 \%$ of $\mathrm{BOD}_{5}$ and $87.62 \pm 2.47 \%$ of $\mathrm{COD}$ using $24.00 \pm 0.39$ and $10.00 \pm 0.07 \mathrm{~h}$ of HRT, respectively. The influence of the environmental variables and operational conditions on kinetic constants was studied; it was determined that the most influential variable for the decay coefficient for heterotrophic biomass was HRT $\left(0.34 \pm 0.14\right.$ and $0.31 \pm 0.10$ days $^{-1}$ with $10.00 \pm 0.07$ and $24.00 \pm 0.39 \mathrm{~h}$ of HRT, respectively), while for heterotrophic biomass yield, this was temperature $(0.61 \pm 0.04$ and $0.52 \pm 0.06$ with $10.00 \pm 0.07$ and $24.00 \pm 0.39 \mathrm{~h}$ of
\end{abstract}

J. Martín-Pascual · C. López-López · E. Hontoria ·

J. M. Poyatos

Department of Civil Engineering, University of Granada,

18071 Granada, Spain

J. Martín-Pascual · P. Reboleiro-Rivas · C. López-López ·

J. González-López · E. Hontoria · J. M. Poyatos $(\bowtie)$

Institute of Water Research, University of Granada,

18071 Granada, Spain

e-mail: jpoyatos@ugr.es
HRT, respectively). The results show that introducing carriers in an MBR system provides similar results for organic matter removal, but with a lower concentration of MLSS.

Keywords Moving bed - Membrane bioreactor . Temperature $\cdot$ Hydraulic retention time

\section{Introduction}

Advanced technologies are needed to preserve surface water quality and to satisfy the regulatory requirements for wastewater. Biological processes that allow complete treatment of the wastewater are required (Trapani et al. 2010), and these can be improved by efficient physical separation technologies such as the use of membranes.

The biological treatment that is currently used most extensively on a global basis is conventional activated sludge (CAS), in which all the biomass in the bioreactor is suspended; the biomass can, however, also be fixed on a carrier, forming a biofilm. Many different biofilm systems have been used, such as trickling filters (Ziolko et al. 2009), rotating biological contactors (Najafpour et al. 2005), fixed media submerged biofilters (Gómez-Silván et al. 2010), granular media biofilters (De Sanctis et al. 2010), continuous-flow reactors (Wang and Wang 2012) or fluidized bed reactors (Sokól et al. 2009). However, in recent years, a new technology based on the use of plastic carriers in continuous motion has been successfully studied, that is, moving bed (MB) technology (Zekker et al. 2012a, b). MB has emerged as a highly effective biological treatment process, offering a compact alternative treatment to conventional activated sludge reactors for the treatment of municipal and industrial wastewater (Ødegaard et al. 1994). It combines the positive aspects of both suspended and attached growth; in contrast to 
most biofilm processes, the entire volume can be used for biomass growth (Ferrai et al. 2010).

The MB process is based on immersion in a bioreactor of carriers with a slightly lower density than water which are continuously in free movement and kept in the tank by a sieve arrangement. The movement of the carrier in the reactor is important to transport substrates to the biofilm and to maintain a low biofilm thickness by shearing forces (Rusten et al. 2006); this is caused by the aeration itself in aerobic systems or by mechanical stirring in anoxic or anaerobic systems. It is recommended that the filling ratio should be below $70 \%$ to be able to maintain the carrier suspension freely (Rusten et al. 2006). The carriers inside the tank are gradually colonized by attached biomass that grows as a biofilm, which is an efficient method for growing nitrifier microorganisms (Kermani et al. 2008). The higher surface area of carriers in biofilm processes provides a greater number of sites for the adsorption and growth of microorganisms. Indeed, attached growth systems are generally considered less sensitive to toxic influents and variations in environmental conditions (Wang et al. 2005). Several studies have demonstrated that, with $\mathrm{MB}$, it is possible to get efficiencies in biochemical oxygen demand $\left(\mathrm{BOD}_{5}\right)$ greater than $90 \%$ and greater than $85 \%$ in chemical oxygen demand (COD) (Germain et al. 2007; Davis et al. 2009; Kim et al. 2010).

In order to improve the yield of CAS, in recent years, a combination of membrane technology with biological treatment using a membrane bioreactor (MBR) has been employed as an innovative and promising option for secondary treatment of municipal wastewater and its reuse. MBR presents an alternative solution for overloaded conventional wastewater treatment plants (WWTP), replacing the settling tank with membrane filtration. It is commonly understood as a combination of membrane filtration and activated sludge as a biological treatment in which the membrane replaces the second clarifier in the wastewater treatment system (Van der Roest et al. 2002). MBR allows the effluent to be of high quality and reduces the number of pathogens present, since the incorporated ultrafiltration membrane has the capacity to retain bacteria and some types of virus (Rodríguez et al. 2011). Indeed, MBR can be operated at higher concentrations of suspended biomass, resulting in long sludge retention times even at smaller reactor volumes (Ahl et al. 2006).

The mixed liquor suspended solids (MLSS) concentration and flux of the membrane affect membrane fouling in MBR processes (Poyatos et al. 2008; Rahimi et al. 2011). An alternative to managing this problem is a hybrid system, in which an MB for biodegradation of soluble organic matter is coupled with an MBR. MB-MBR has the potential to utilize the best characteristics of both biofilm processes and membrane separation (Ivanovic and Leiknes
2008). Using this technology, the biofilm system may reduce the concentration of suspended solids and improve the extent of membrane fouling. In summary, MB-MBR versus MBR has the potential to be even more compact, operating with higher fluxes, greater energy efficiency, and with better fouling control, therefore providing optional strategies for minimizing fouling (Ivanovic et al. 2008). In relation to organic matter removal, several studies of $\mathrm{MB}-$ MBR technology have obtained COD removal efficiency greater than $93 \%$ (Leiknes and Ødegaard 2007; Yang et al. 2009, 2010; Yang and Yang 2011).

The design criteria for MB are based on assumptions about the surface loading rate and the retention time in order to achieve the required effluent quality (Ferrai et al. 2010); however, to design conventional biological wastewater treatments, kinetic modeling for heterotrophs and autotrophs has become an important tool. Although activated sludge models have wide applications in the field of engineering (Plattes et al. 2008), in a hybrid systems, the competition for availability of the substrates between attached and dispersed biomass leads to modifications in the kinetic parameters of both biomass components (Trapani et al. 2010). Indeed, there remain many doubts regarding the kinetic parameters of hybrid reactors, which probably differ markedly from those of pure $\mathrm{MB}$ and CAS reactors, and for which, furthermore, there is a lack of experimental study (Mannina and Viviani 2009).

The aim of this study was to evaluate the effectiveness of an innovative moving bed membrane bioreactor system fed with real urban wastewater. The ability of the system to remove organic matter was investigated in relation to the hydraulic retention time, mixed liquor suspended solids and the temperature through the kinetic study of the hybrid biomass that includes attached biomass in carriers compared to other conventional systems. Statistical relationships with the environmental variables were determined. An urban wastewater moving bed membrane bioreactor treatment pilot plant in Granada (Spain) was used for this study between January and June of 2011.

\section{Materials and methods}

Experimental procedure

\section{Description of the pilot-scale experimental plant}

In this research, a pilot-scale experimental plant was used. A schematic of the process configuration and pilot plant used is shown in Fig. 1. The pilot plant was situated at the Puente de Los Vados WWTP in Granada, Spain. The urban wastewater used was taken from the outlet of the primary 
Fig. 1 Schematic diagram of the studied MB-MBR pilot plant

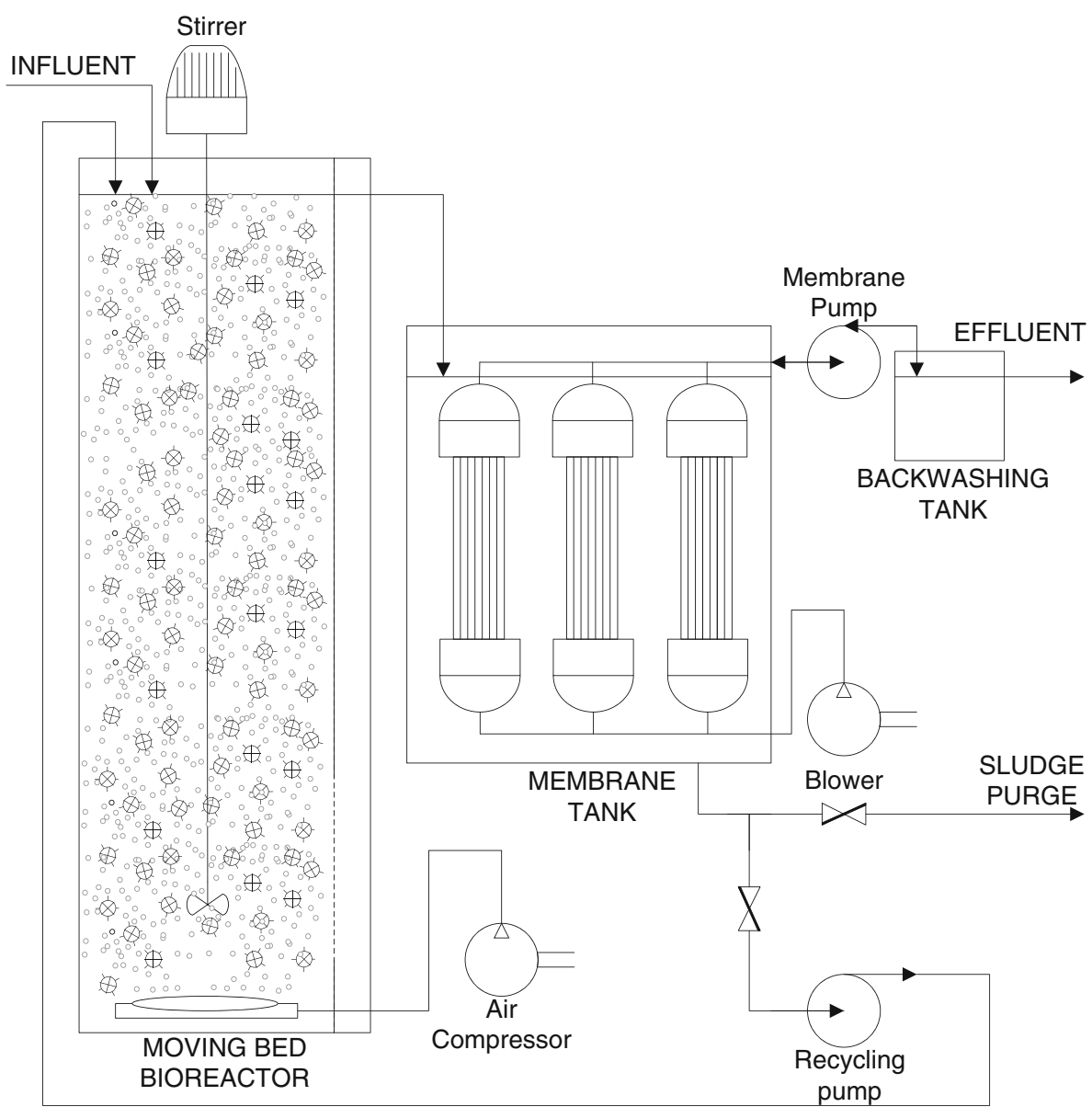

settler, so this wastewater had been mechanically pretreated before being fed to the pilot plant. The experimental plant used in this research had two bioreactors: a cylindrical bioreactor with an operating volume of $358 \mathrm{~L}$ in which carriers were contained, and a rectangular tank with $87 \mathrm{~L}$ of operating volume in which three Zenon ${ }^{\circledR}$ hollow fiber ultrafiltration membrane units were submerged. The modules used were ZW-10, configured as an outside/in hollow fiber with a nominal membrane surface area of $0.93 \mathrm{~m}^{2}$, a nominal pore size of $0.04 \mu \mathrm{m}$ and an absolute pore size of $0.1 \mu \mathrm{m}$. The typical operating transmembrane pressure of this module is $10-50 \mathrm{kPa}$ with a maximum transmembrane pressure of $62 \mathrm{kPa}$. Maximum nominal permeate flux of the units of membrane checked by Poyatos et al. (2008) was $29.9 \mathrm{~L} / \mathrm{m}^{2} \mathrm{~h}$; however, 20.57 $\mathrm{L} / \mathrm{m}^{2} \mathrm{~h}$ is recommended in order to avoid critical flux. Biodegradation took place in the first bioreactor $(\mathrm{MB})$, followed by a membrane reactor with submerged modules in which solid separation occurred. In order to maintain the concentration of biomass in the $\mathrm{MB}$, a recycling pump with a constant flow of $90 \mathrm{~L} / \mathrm{h}$ took the sludge from the membrane tank to the MB. The excess sludge was extracted under constant flow in each condition, as this is related to the operational conditions.
The carrier used was K1, a carrier developed by AnoxKaldness. It is a cylindrical high-density polyethylene ring, with a cross-shaped cut-out, which is $11 \mathrm{~mm}$ in length, $10 \mathrm{~mm}$ in diameter and $7 \mathrm{~mm}$ in height. Its density is $0.92-0.96 \mathrm{~g} / \mathrm{cm}^{3}$ and its specific surface area is $800 \mathrm{~m}^{2} /$ $\mathrm{m}^{3}$ with an effective surface area for biofilm growth of $500 \mathrm{~m}^{2} / \mathrm{m}^{3}$. This carrier has been widely studied in moving bed research by other authors, such as Melin et al. (2005), Canziani et al. (2006), Leiknes and Ødegaard (2007) and Falletti and Conte (2007). Also, similar carriers, such as Bioflow 9 Media, have been used in other studies (Zekker et al. 2011, 2012a). The carriers were contained in the cylindrical reactor with a $20 \pm 0.19 \%$ filling ratio (rate between the apparent carrier volume and the operational volume of the bioreactor).

\section{Operating conditions}

Two phases of operation were studied by varying the hydraulic retention time (HRT), which in the first phase was $10 \mathrm{~h}$ and in the second $24 \mathrm{~h}$; the MB-MBR was operated at a flow rate of $45.5 \mathrm{~L} / \mathrm{h}$ in phase 1 and $18.96 \mathrm{~L} / \mathrm{h}$ in phase 2. The membrane reactor was designed as an external submerged unit in which the dimensions of the 
reactor were adjusted only for particle separation. During the study, two different modes of membrane operation were applied: continuous filtration and periodic backwashing. The cyclic mode of operation consisted primarily of a production period of 9.67 with 0.33 min backwash. The submerged membrane units were operated at a constant flux using a suction pump in each phase (15.80 and $6.58 \mathrm{~L} / \mathrm{m}^{2} \mathrm{~h}$, respectively), and the transmembrane pressures (TMP) varied between 0.3 and 0.5 bar. Air scouring of the membrane was applied continuously.

The start-up of the pilot plant consisted in feeding the pilot plant with urban wastewater from the primary settler of the wastewater treatment plant of Los Vados in Granada (Spain), where the plant was situated. The pilot plant worked under the conditions of each phase until the MLSS obtained the required value, at which point a purge flow was initiated in order to stabilize the biomass.

\section{Physical and chemical determination}

The water samples (three replicates) were obtained for analytical determination every $24 \mathrm{~h}$ from the feed tank, biological reactor and permeate. A sample $(1 \mathrm{~L})$ was conserved from each assayed point in the laboratory at $4{ }^{\circ} \mathrm{C}$ for physical and chemical tests and was analyzed within $4 \mathrm{~h}$ of sampling.

The COD and $\mathrm{BOD}_{5}$ were determined according to the American Public Health Association, the American Water Works Association and the Water Environment Federation (APHA-AWWA-WEF) method. The solids in suspension (SS) were determined by gravimetric methods (APHA 1992). The $\mathrm{pH}$ was determined using a $\mathrm{pH}$ meter (Crison $\mathrm{pH} 25^{\circledR}$ ), and conductivity was determined using a conductivity meter (Crison CM $35^{\circledR}$ ).

Tests on carrier samples were carried out in order to establish the amount of biomass attached to the carriers. The biofilm solids were determined by sampling five carrier elements. Attached biomass was assessed by considering the solids in suspension on the support carriers as described by Martín-Pascual et al. (2012).

Determination of kinetic constants: respirometric method

The objective of a respirometer assay is to reproduce the microbial processes of substrate consumption that occur in a bioreactor and assesses the process through fundamental standard measurements, such as oxygen uptake rate (OUR) and oxygen consumed (OC). The respirometric tests were done as described by Martín-Pascual et al. (2012) with a BM-Advance respirometer.
The microbial growth yield of heterotrophic biomass $\left(Y_{\mathrm{H}}\right)$ determines how much biomass must be employed to consume a pre-determined amount of substrate. $Y_{\mathrm{H}}$ is defined as the incremental increase in heterotrophic biomass $(\Delta X)$ which results from the utilization of an incremental amount of substrate $(\Delta S)$. In order to calculate $\Delta X$, it can be approximated in relation to the oxygen consumed due to the added substrate (OC) and the initial and final substrate concentration $\left(S_{0}\right.$ and $\left.S\right)$, as shown in Eq. 1.

$\Delta X=\left(S_{0}-S\right)+\left(\mathrm{OC}_{0}-\mathrm{OC}\right)=S_{0}-\mathrm{OC}$

Considering that the substrate that is not oxidized is used for growth, that all of the added substrate is utilized and that the oxygen concentration in the initial moment $\left(\mathrm{OC}_{0}\right)$ is zero (Helle 1999), $Y$ can be calculated as shown in Eq. 2.

$Y_{H}=\frac{S_{0}-\mathrm{OC}}{S_{0}}=1-\left(\frac{\mathrm{OC}}{S_{0}}\right)$

$S_{0}$ was determined as the product of sample volume and DQO concentration, and the amount of OC was calculated from the dynamic respiration rate of the respirogram.

The specific growth rate for heterotrophic biomass $\left(\mu_{\mathrm{H}}\right)$ is defined by the change in the heterotrophic active biomass $\left(X_{\mathrm{H}, \mathrm{Vss}}\right)$ over time (Eq. 3 ). The model of microbial growth used in the present research is based on the Monod model (Eq. 4), for which $\mu_{\mathrm{H}}$ under substrate concentration $(S)$ of a single growth-limiting substrate is defined through the maximum specific growth rate for heterotrophic biomass $\left(\mu_{\mathrm{H}, \mathrm{MAX}}\right)$ and the substrate saturation constant $\left(K_{\mathrm{s}}\right)$ in the absence of endogenous metabolism (Judd 2010). Models based on saturation kinetics like this suggest that $\mu_{\mathrm{H}}$ is approximately proportional to $S$ at substrate concentrations below $K_{\mathrm{s}}$, while, at higher values of $S, \mu_{\mathrm{H}}$ is independent of the substrate concentration; $\mu_{\mathrm{H}, \mathrm{MAX}}$ occurs when $S$ is infinity.

$\mu_{\mathrm{H}}=\frac{d X_{\mathrm{H}, \mathrm{VSS}}}{d t} \frac{1}{X_{\mathrm{H}, \mathrm{VSS}}}$

$\mu_{\mathrm{H}}=\mu_{\mathrm{H}, \mathrm{MAX}} \frac{S}{K_{\mathrm{S}}+S}$

The death of microorganisms and the subsequent utilization of the cellular material by the remaining microbes (microbial decay) can be included in the Monod model by adding a first-order reaction for microbial decay (Eq. 5) due to the change in biomass concentration when $S$ is equal to zero is due to microbial decay (Helle 1999), so $\mu_{\mathrm{H}}$ can be defined as described in Eq. 6.

$\frac{\mathrm{dX}}{\mathrm{dt}}=b_{\mathrm{H}} X$

$\mu_{\mathrm{H}}=\mu_{\mathrm{H}, \mathrm{MAX}} \frac{S}{K_{\mathrm{S}}+S}$ 
The model decay coefficient, $\left(b_{\mathrm{H}}\right)$, can be calculated from Eq. 7 (Henze et al. 2000), where $b_{\mathrm{H}}^{\prime}$ obtained from the specific oxygen uptake rate of the respirogram.

$b_{\mathrm{H}}=\frac{b_{\mathrm{H}}^{\prime}}{1-Y_{\mathrm{H}, \mathrm{VSS}}\left(1-f_{\mathrm{p}}\right)}$

Statistical analysis

The data obtained throughout this study were analyzed using a computer-assisted statistics program, SPSS 13.0 for Windows. A least significant differences test (LSD test) was used to measure the differences between the obtained results $\left(\mathrm{COD}\right.$ and $\mathrm{BOD}_{5}$ ) for the different operational conditions studied $\left(\mathrm{pH}\right.$, conductivity, COD, BOD $5, \mathrm{MLSS}_{\mathrm{t}}$, $\mathrm{MLSS}_{\mathrm{v}}$ and $\mathrm{MLSS}_{\mathrm{f}}$ of the influent, $\mathrm{pH}$, conductivity, temperature and $\mathrm{MLSS}_{\mathrm{t}}, \mathrm{MLSS}_{\mathrm{v}}$ and $\mathrm{MLSS}_{\mathrm{f}}$ of the bioreactor). Normality tests of the data were done using the Shapiro-Wilk test since the dataset was smaller than 2,000 elements. An analysis of variance (ANOVA) was used to assess the homogeneity of variance, with a significance level of $5 \%(P<0.05)$.

A multivariable analysis in Canoco for Windows version 4.5 was used to quantify the influence of the environmental variables (biomass concentration, temperature and HRT) on the kinetic constants. A Monte Carlo test of permutations (499 permutations) was performed, with a selected significance level of 0.05 .

\section{Results and discussion}

The study conditions for this research are shown in Table 1. The main variable was HRT, which was first set to $10.00 \pm 0.07 \mathrm{~h}$ and then changed to $24.00 \pm 0.39 \mathrm{~h}$. Batch tests are a well-known technique describing actual activity, and this kind of assay has been used to study the effect of different operational variables one by one (Zekker et al. 2012a, c). However, the present research was conducted as a continuous experiment to reproduce the real conditions of a wastewater treatment plant. Four periods were differentiated: The first included the start-up and biomass stabilization of the pilot plant, beginning with the arrival of influent to the pilot plant until the biomass was stabilized under the regime of $10.00 \pm 0.07 \mathrm{~h}$ of HRT. The required biomass was reached on the 33rd day and the purge then commenced. On day 60, when concentration of the attached biofilm was stable and the total volume of mixed liquor had been purged at least twice, the first phase began, assuming this phase as a steady-state condition under the regime of $10.00 \pm 0.07 \mathrm{~h}$ of HRT until the 80th day, at which point the HRT was changed to a regime of $24.00 \pm 0.39 \mathrm{~h}$. The start-up and biomass stabilization of phase 2, under a regime of $24.00 \pm 0.39 \mathrm{~h}$ of HRT, operated until day 134, and day 135 was considered as the steady-state condition of the pilot plant under these conditions (phase 2). The purge flow was established to maintain the MLSS under the different HRT regimes, and the solids retention time (SRT) was obtained according to the purge flow; in phase 1 , the purge flow was $50 \mathrm{~L} /$ day and SRT was $9.0 \pm 0.5$ days, and in phase 2, SRT was $18.5 \pm 1.2$ days and the purge flow was $24 \mathrm{~L} /$ day.

The average biomass concentration of the biofilm increased during the study, as shown in Table 1. The attached biomass allowed for higher removal efficiencies for organic matter but increased membrane fouling since the concentration of the mixed liquor was lower (Germain et al. 2005). Figure 2 shows the evolution of MLSS (totals and volatiles) in the bioreactor. Due to the variability of the effluent, several concentration levels can be seen; however, during the stationary state, the biomass in the reactor was relatively constant at about 2,494 \pm 155 and 2,554 \pm 168 $\mathrm{mg} / \mathrm{L}$ of MLSS under the respective regimes of $10.00 \pm 0.07$ and $24.00 \pm 0.39 \mathrm{~h}$ of HRT. The $\mathrm{pH}$, conductivity, concentration of suspended solids and concentration of organic matter in the influent during the different phases studied in this research are shown in Table 2. Several studies with similar concentration of MLSS with the same carrier type have shown an attached biofilm density near the values of the present research (Sriwarat and Randal 2005; Rutt et al. 2006; Kim et al. 2010). The values obtained were analyzed statistically to ensure that the different studied phases were comparable. The ANOVA showed that there were no statistically significant differences between the influent in the different phases, and so the homogeneity of the effluent allowed for a comparative study of the behavior of the pilot plant in which the operational conditions were the only changing factor.

The presence of an ultrafiltration membrane separating the physical system ensured that suspended solids were not present in the effluent. Figure 3 shows the values of COD (Fig. 3 a) and $\mathrm{BOD}_{5}$ (Fig. 3 b) for the days on which the research was undertaken. The average yield of organic matter removed $\left(\mathrm{BOD}_{5}\right.$ and $\left.\mathrm{COD}\right)$ during the different studied phases was greater than $87.62 \%$ for COD and $89.37 \%$ for $\mathrm{BOD}_{5}$, greater than those found in other research under similar conditions (Trapani et al. 2010). The yield of removed COD increased when the HRT increased, showing an average value of $87.62 \pm 2.47 \%$ during the stationary phase of the lowest HRT and $93.44 \pm 2.13 \%$ in the stationary phase of the highest HRT. The yield during the start-up of each phase showed the same trend with median values of $89.78 \pm 3.36 \%$ and $90.58 \pm 4.04 \%$ in phase 1 and 2, respectively; the differences were lower in the start-up phase since the biomass of the system had not stabilized yet. During this study, similar values of removed COD as in other studies with MBR under a higher 
Table 1 Operational conditions for the different phases studied during this research: hydraulic retention time (HRT); temperature; concentration of suspended solids both mixed liquor and attached biomass and Feed/Mass rate

\begin{tabular}{|c|c|c|c|c|c|c|c|}
\hline \multirow[t]{2}{*}{ Phase } & \multirow[t]{2}{*}{ HRT (h) } & \multirow[t]{2}{*}{ Average temperature $\left({ }^{\circ} \mathrm{C}\right)$} & \multicolumn{2}{|l|}{ Mixed liquor } & \multicolumn{2}{|c|}{ Attached biofilm density } & \multirow{2}{*}{$\begin{array}{l}\mathrm{F} / \mathrm{M} \text { rate } \\
\left(\mathrm{KgDBO}_{5} /\right. \\
\mathrm{KgMLSST} \text {. day }\end{array}$} \\
\hline & & & SSt (mg/L) & $\mathrm{SSv}(\mathrm{mg} / \mathrm{L})$ & $\begin{array}{l}\mathrm{SSt} \\
\text { (mg/L of } \\
\text { carrier) }\end{array}$ & $\begin{array}{l}\mathrm{SSv} \\
\text { (mg/L of } \\
\text { carrier) }\end{array}$ & \\
\hline Start-up phase 1 & $10.00 \pm 0.07$ & $9.4 \pm 2.3$ & $1,940 \pm 590$ & $1,632 \pm 503$ & $1,880 \pm 490$ & $1,548 \pm 463$ & $0.63 \pm 0.87$ \\
\hline Phase 1 & $10.00 \pm 0.07$ & $14.8 \pm 1.5$ & $2,494 \pm 155$ & $2,052 \pm 177$ & $2,618 \pm 272$ & $2,145 \pm 348$ & $0.39 \pm 0.07$ \\
\hline Start-up phase 2 & $24.00 \pm 0.39$ & $17.1 \pm 1.5$ & $2,288 \pm 451$ & $1,897 \pm 400$ & $3,542 \pm 521$ & $3,081 \pm 557$ & $0.16 \pm 0.06$ \\
\hline Phase 2 & $24.00 \pm 0.39$ & $20.6 \pm 1.5$ & $2,554 \pm 168$ & $2,077 \pm 185$ & $4,341 \pm 472$ & $3,716 \pm 404$ & $0.13 \pm 0.05$ \\
\hline
\end{tabular}

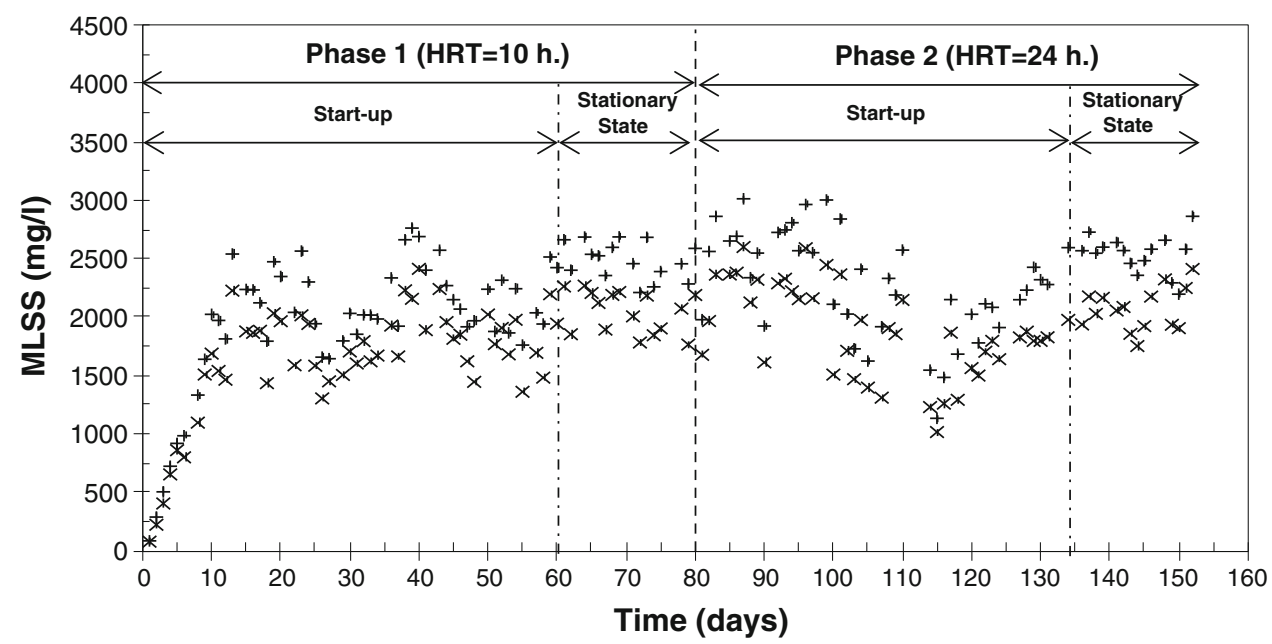

Fig. 2 Evolution of mixed liquor total suspended solids $(+)$ and mixed liquor volatile suspended solids $(X)$ of the bioreactor of the pilot plant during different phases of the study: the start-up of phase 1 (from day 1 to 59), when from day 1 to 33, the biomass increased, and on day 34 , the purge began maintaining the biomass concentration relatively stable; the stationary state of phase 1 (from day 60 to 80); stabilizing of phase 2 (from day 81 to 134 ); and the stationary portion of phase 2 (from day 135 to 152 )

Table 2 Characteristics of the effluent during the research (pH conductivity

\begin{tabular}{lcccc}
\hline & Start-up phase 1 & Phase 1 & Start-up phase 2 & Phase 2 \\
\hline $\mathrm{pH}$ & $7.85 \pm 0.11$ & $7.62 \pm 0.16$ & $7.63 \pm 0.22$ & $7.52 \pm 0.31$ \\
Conductivity $(\mu \mathrm{S} / \mathrm{cm})$ & $1,132.48 \pm 299.19$ & $1,239.00 \pm 219.66$ & $968.81 \pm 358.98$ & $962.07 \pm 429.64$ \\
$\mathrm{COD}\left(\mathrm{mgO}_{2} / \mathrm{L}\right)$ & $491.21 \pm 112.40$ & $556.00 \pm 90.63$ & $479.77 \pm 101.78$ & $479.15 \pm 104.22$ \\
$\mathrm{BOD}_{5}\left(\mathrm{mgO}_{2} / \mathrm{L}\right)$ & $375.59 \pm 90.97$ & $408.82 \pm 64.51$ & $362.25 \pm 71.09$ & $349.29 \pm 89.57$ \\
$\mathrm{SSt}(\mathrm{mg} / \mathrm{L})$ & $145.79 \pm 44.09$ & $150.94 \pm 30.78$ & $128.62 \pm 41.50$ & $113.46 \pm 40.61$ \\
$\mathrm{SSv}(\mathrm{mg} / \mathrm{L})$ & $124.88 \pm 38.47$ & $116.12 \pm 40.88$ & $109.22 \pm 33.81$ & $95.33 \pm 40.26$ \\
\hline
\end{tabular}

Concentration of suspended solids and concentration of organic matter measured as $\mathrm{BOD}_{5}$ and $\mathrm{COD}$ )

concentration of MLSS were reached due to the fraction of biomass attached to the carrier. Krzeminski et al. (2012), with an MLSS higher than $8.3 \mathrm{~g} / \mathrm{L}$ and a HRT higher than that used in phase 2 of the present study, obtained $94.1 \%$ removal efficiency of COD with a similar COD in the influent. The yield of COD removed reached after $24.00 \pm 0.39 \mathrm{~h}$ of HRT was greater than the $91 \%$ obtained by Gomez et al. (2012) under a higher MLSS $(4.2 \mathrm{~g} / \mathrm{L})$ and HRT $(>24 \mathrm{~h})$. This shows that it is possible to reduce the MLSS of the bioreactor without reducing the removal efficiency of the system. The energy demands of the MBR increase with MLSS (Martín-Pascual et al. 2012), so if the MLSS concentration of the MB bioreactor is lower than that of the MBR, the energetic costs of the MB bioreactor are lower than the MBR as well, since less aeration is required. Since differences in COD removed were obtained in the different phases, it is possible to analyze the influence of HRT. A higher rate of substrate removal was 
Fig. 3 COD (a) and $\mathrm{BOD}_{5}$ (b) of the influent $(+)$ and the effluent $(X)$ of the pilot plant during the different phases of the study
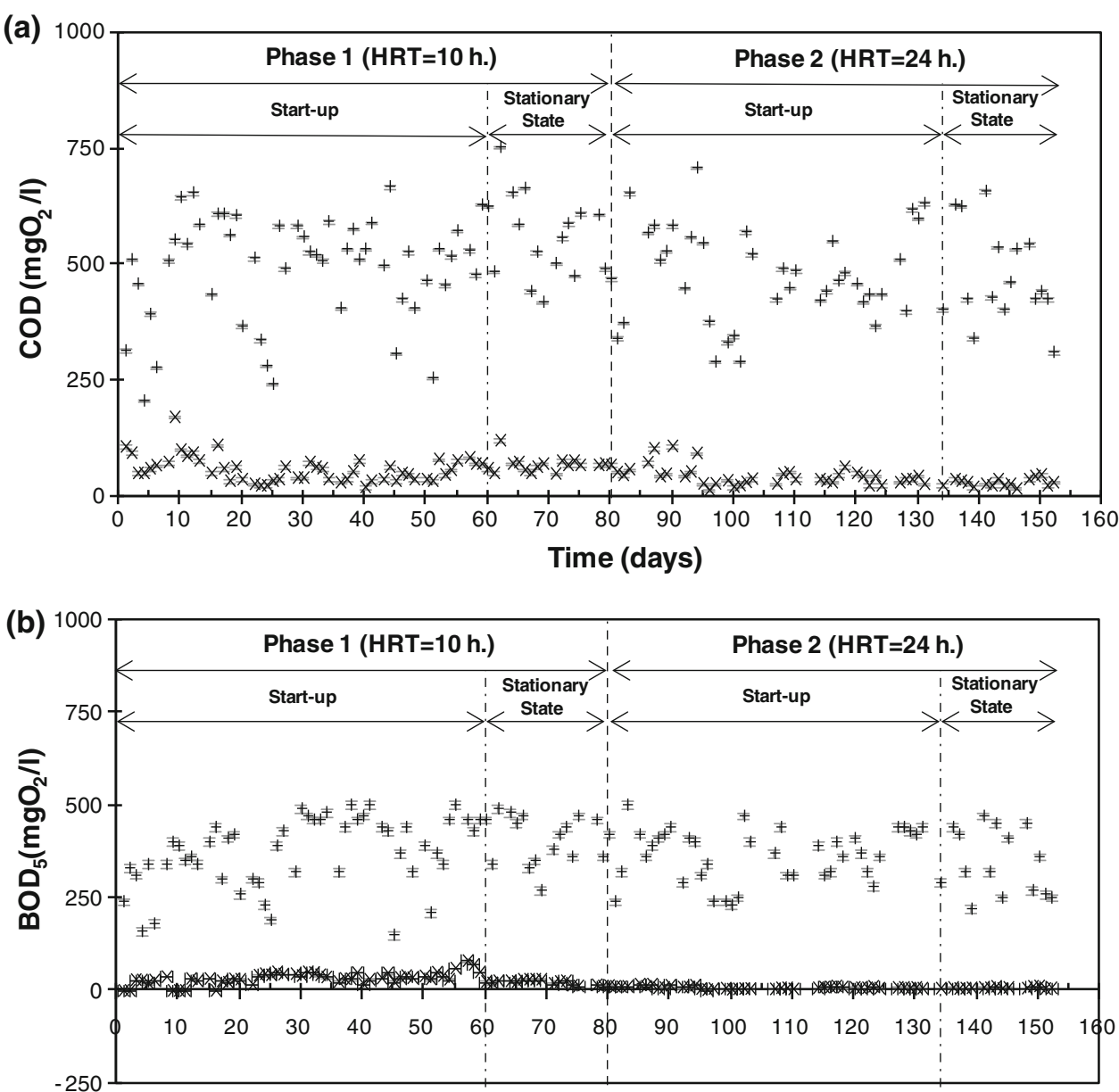

Time (days) obtained when the HRT was higher; this was confirmed using ANOVA in which statistically significant differences were observed between the start-up of phase 1 and the start-up of phase 2 and phase $2(P=0.039$ and 0.001 , respectively), and between phase 1 and phase 2 $(P=0.008)$. However, under the same HRT regime, statistically significant differences were not observed for the different phases.

The yields of removed $\mathrm{BOD}_{5}$ showed a similar trend to COD, with average values of $94.41 \pm 2.26$ and $97.73 \pm$ $0.81 \%$ in phase 1 and 2 , respectively, and $89.37 \pm 3.65$ and $97.75 \pm 0.94 \%$ in the start-up of phase 1 and phase 2 , respectively. The biomass attached as a biofilm allowed a yield of removed organic matter that was similar to the results of other research conducted without a carrier under a regime with a higher concentration of MLSS; for example, Rodriguez et al. (2012) using an MBR system under a regime of $12 \mathrm{~h}$ of HRT and 4,017 mg/L of MLSS obtained a BOD 5 yield of $96.4 \%$. Statistical study of this parameter revealed that there were statistically significant differences between the different phases, with the only exception as the start-up of phase 2 and phase 2 in which the yield was similar. In relation to organic matter removal efficiency, this study showed that it is possible to reach similar COD and $\mathrm{BOD}_{5}$ in an $\mathrm{MB}-$ MBR working under a lower concentration of MLSS in the MBR due to the attached biomass of the system, allowing for a reduction in some of the disadvantages of the MBR caused by the high concentration MLSS.

An important aspect to study in the biological process of wastewater treatment is kinetic modeling. A new respirometer test was used in this research in order to include the combined effect of the dispersed and attached biomass of the system, allowing a reproduction of the real kinetic behavior of the process. Kinetic studies were performed weekly to analyze the influence of the different conditions on the behavior of the biomass present in the bioreactor. This study allowed an analysis of the evolution of the kinetic parameters for heterotrophic biomass studied under different conditions during our research. Table 3 shows the average kinetic constants studied $\left(Y_{\mathrm{H}}, b_{\mathrm{H}}, \mu_{\mathrm{H}, \mathrm{MAX}}\right.$ and $\left.K_{\mathrm{S}}\right)$ during the study. In this calculation, the biomass concentration was defined as the biomass present in both the mixed and attached liquor in the carrier, measured as volatile suspended solids. Initially, the decay coefficient showed an average value of 
Table 3 Average value of the kinetics parameter for heterotrophic biomass under different conditions studied during the research

\begin{tabular}{lllll}
\hline Phase & $Y_{\mathrm{H}, \mathrm{vss}}$ & $b_{\mathrm{H}}(1 /$ day $)$ & $\mu_{\mathrm{H} . \mathrm{MAX}}(1 /$ day $)$ & $K_{\mathrm{S}}(\mathrm{KgO} / \mathrm{Kg}$ day $)$ \\
\hline Start-up phase 1 & $0.51 \pm 0.08$ & $0.12 \pm 0.06$ & $1.01 \pm 0.79$ & $15.2 \pm 12.2$ \\
Phase 1 & $0.61 \pm 0.04$ & $0.34 \pm 0.14$ & $1.21 \pm 0.54$ & $5.01 \pm 0.10$ \\
Start-up phase 2 & $0.61 \pm 0.03$ & $0.63 \pm 0.21$ & $0.86 \pm 0.45$ & $3.07 \pm 0.59$ \\
Phase 2 & $0.52 \pm 0.06$ & $0.31 \pm 0.10$ & $0.76 \pm 0.31$ & $5.78 \pm 1.56$ \\
\hline
\end{tabular}

$Y_{\mathrm{H}}$ is the yield for heterotrophic biomass; $b_{\mathrm{H}}$ the decay coefficient; $\mu_{\mathrm{H} . \mathrm{MAX}}$ the specific growth rate for heterotrophic biomass; and $K_{\mathrm{S}}$ the halfsaturation coefficient for heterotrophic biomass

$0.12 \pm 0.06$ day $^{-1}$; this value was measured according to the lower concentration of the biomass present in the system, and the values obtained during phases 1 and 2 were similar $\left(0.34 \pm 0.14\right.$ and $0.31 \pm 0.10$ day $^{-1}$, respectively). These values are similar to those obtained by Canziani et al. (2006). However, the value for $b_{H}$ in the start-up of phase 2 was higher $\left(0.63 \pm 0.21 \mathrm{day}^{-1}\right)$ due to the change in the operational conditions, causing a shock to the microorganisms which had to adapt to new conditions. Similar trends were observed in the evolution of the half-saturation coefficient for heterotrophic biomass, with similar average values in phases 1 and $2\left(5.01 \pm 0.10\right.$ and $5.78 \pm 1.56 \mathrm{kgO}_{2} /$ $\mathrm{kg} \mathrm{day}^{-1}$, respectively). The values of $Y_{\mathrm{H}, \mathrm{vss}}$ were slightly lower than the typical values of neutral $\mathrm{pH}$ (Henze et al. 2000), with average values of $0.51 \pm 0.08,0.61 \pm 0.04$, $0.61 \pm 0.03$ and $0.52 \pm 0.06$ during the start-up of phase 1 , phase 1, the start-up of phase 2 and phase 2, respectively; however, these values were similar to those found for an MBR system with MLSS between 3 and $6.5 \mathrm{~g} / \mathrm{L}$ obtained by Di Trapani et al. (2011). The lowest value in the start-up of phase 1 could be due to the lower concentration of biomass present in the bioreactor. The yield of heterotrophic biomass $\left(Y_{\mathrm{H}, \mathrm{vss}}\right)$ and the maximum specific growth rate for heterotrophic biomass $\left(\mu_{\mathrm{H}, \mathrm{MAX}}\right)$ showed lower values in HRT higher due to the organic load under these conditions being lower, with therefore less availability of substrate for the microorganisms present in the system. The highest value of $\mu_{\mathrm{H}, \mathrm{MAX}}$ was $1.21 \pm 0.54$ in phase 1 with $2,052 \pm 177 \mathrm{mg} / \mathrm{L}$ of MLSS and $10.00 \pm 0.07 \mathrm{~h}$ of HRT. This value was higher than the value obtained by Plattes et al. (2006) with a filling ratio of $65 \%, 2.230 \mathrm{mg} / \mathrm{L}$ of biomass and $8 \mathrm{~h}$ of HRT. Ferrai et al. (2010) had similar values of $\mu_{\mathrm{H}, \mathrm{MAX}}$ and $Y_{\mathrm{H}, \mathrm{vss}}$ to those obtained in this study.

A multivariate statistical study using the software Canoco for Windows 4.5 was undertaken to analyze the influence of HRT, bioreactor temperature and total biomass present in the system (measured as suspended solids and volatiles) on the kinetic constants due to difficulties with including environmental parameters in modeling the constant. A detrended correspondence analysis (DCA), as the most appropriate ordination statistical analysis, was carried out to obtain the gradient lengths. DCA revealed the longest ordination axis to be less than three, and so the

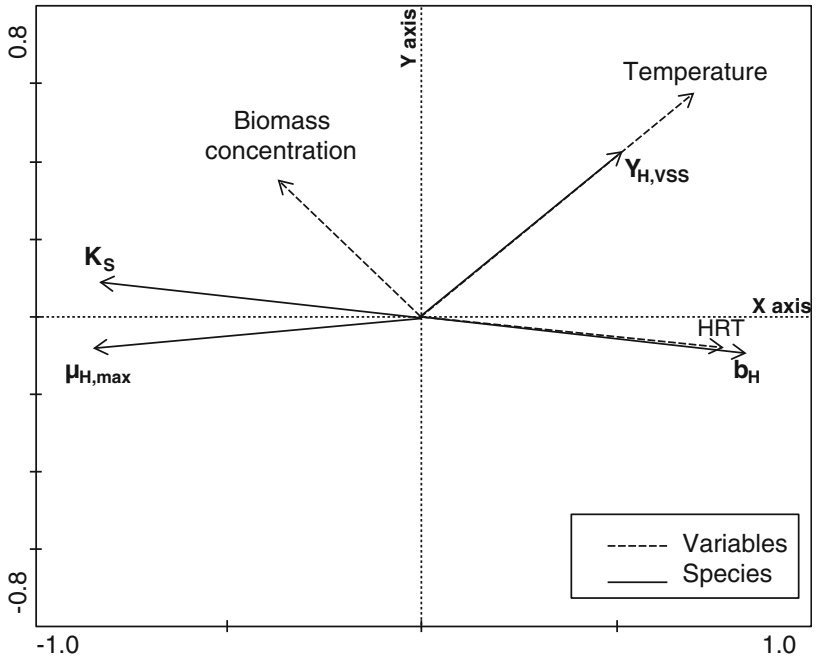

Fig. 4 Graph of the results from the multivariable analysis used to study the relationship between HRT, temperature of the bioreactor and biomass as variables, and $K \mathrm{~s}, \mathrm{KD}, \mu_{\mathrm{H}, \text { max }}$ and $Y_{\mathrm{H}, \mathrm{VSS}}$ as species for the conditions tested in this study

distribution of the model was linear. Redundancy analysis (RDA) was therefore used as the statistical method recommended for gradients with a linear response (Lepš and Šmilauer 1999). Statistical significance was tested using a Monte Carlo permutation test with 499 permutations. Two of the variables studied presented $P$ values lower than 0.05 : These variables were HRT $(P=0.006)$ and temperature $(P=0.012)$. The results of the analysis are shown in a triplot diagram (Fig. 4). The model represents $68.1 \%$ of the variance of species data on the first axis and $1.8 \%$ on the second axis, and so $69.9 \%$ of the cumulative variance is represented between the two first axes. Considering the relationship between species and environmental variables, 97.4 and $99.9 \%$ of cumulative the variance is included in the two mean axes, respectively. So, the first axis (horizontal) describes $97.4 \%$ of the variance of the kinetic constants for all environmental variables considered in this analysis, and $68.1 \%$ of the total variance of the system. The most influential variable on this axis is HRT. The second axis (vertical) describes $2.5 \%$ of the variance of the kinetic constants studied for all the variables considered in this analysis, and $1.8 \%$ of the total variance of the system. 
Temperature is the most significant environmental variable on this axis.

Figure 4 shows the correlations between the kinetic constants and the studied variables (temperature, biomass concentration and HRT). The vector representing cell decay and the decay coefficient for heterotrophic biomass $\left(b_{\mathrm{H}}\right)$ follow the same direction and sense of the HRT vector, implying that as HRT increases, so does $b_{\mathrm{H}}$. HRT and SRT are closely related, in that SRT is higher when HRT is higher, and cell lyses increases, so $b_{\mathrm{H}}$ must also be higher. If biomass temperature is greater, the microbial activity increases, so the yield for heterotrophic biomass $\left(Y_{\mathrm{H}, \mathrm{VSS}}\right)$ is higher. Ruiz et al. (2011) showed that the influence of temperature on $Y_{\mathrm{H} \text {,vss }}$ is such that this parameter increases as temperature increases, but shows a maximum value when the temperature rises above $20{ }^{\circ} \mathrm{C}$, since the range of temperatures tested in this research (Table 1) was lower than $20^{\circ} \mathrm{C}$. Temperature could therefore have a considerable influence on the process. The maximum specific growth rate $\left(\mu_{\mathrm{H} \text {,max }}\right)$ is inversely proportional to HRT as a result of the adaptability of the biological process to the pollution loading rate of the influent.

\section{Conclusion}

Given the results obtained under the MLSS studied and the regimes of $10.00 \pm 0.07$ and $24.00 \pm 0.39 \mathrm{~h}$ HRT using technology with attached and dispersed biomass, the following conclusions were made:

1. A moving bed/membrane bioreactor system under the conditions studied in this research removed $93.44 \pm$ $2.13 \%$ of COD, $97.73 \pm 0.81 \%$ of $\mathrm{BOD}_{5}, 87.62 \pm$ $2.47 \%$ of $\mathrm{COD}$ and $94.41 \pm 2.26 \%$ of $\mathrm{BOD}_{5}$ under regimes of $10.00 \pm 0.07$ and $24.00 \pm 0.39 \mathrm{~h}$ of HRT, respectively.

2. The yield for heterotrophic biomass was $0.61 \pm 0.04$ and $0.52 \pm 0.06$ with $10.00 \pm 0.07$ and $24.00 \pm$ $0.39 \mathrm{~h}$ of HRT, respectively, and the decay coefficient for heterotrophic biomass was $0.34 \pm 0.14$ and $0.31 \pm$ 0.10 days $^{-1}$ with $10.00 \pm 0.07$ and $24.00 \pm 0.39 \mathrm{~h}$ of HRT, respectively.

3. The most influential variable in the decay coefficient for heterotrophic biomass $\left(b_{\mathrm{H}}\right)$ was HRT, and for the heterotrophic biomass $\left(Y_{\mathrm{H}, \mathrm{vSS}}\right)$ yield, the most influential variable was temperature.

In view of these results, the moving bed membrane bioreactor investigated in the present study had yields of organic matter removal close to a membrane bioreactor operating with higher MLSS. Therefore, this technology could reduce the energetic demands and fouling problems associated with MBR technology.
Acknowledgments This research was supported by the Spanish Ministry of Science and Technology under project reference CTM2009-11929-C02-01 and by the University of Granada through a personal grant to J. Martín-Pascual. This research was also made possible thanks to the participation of Empresa Municipal de Abastecimiento y Saneamiento de Granada (EMASAGRA).

\section{References}

Ahl RM, Leiknes T, Ødegaard H (2006) Tracking particle size distributions in a moving bed biofilm membrane reactor for treatment of municipal wastewater. Water Sci Technol 53:33-42

APHA (1992) Standard Methods for the Examination of Water and Wastewater, 18th edn. American Public Health Association, Washington DC

Canziani R, Emondi V, Garavaglia M, Malpei F, Pasinetti E, Buttiglieri G (2006) Effect of oxygen concentration on biological nitrification and microbial kinetics in a cross-flow membrane bioreactor (MBR) and moving-bed biofilm reactor (MBBR) treating old landfill leachate. J Membr Sci 286:202-212

Davis JA, Harrison K, Shields B (2009) Compact technology: increasing treatment capacity without building more basins. Fla Water Resour 7:24-29

De Sanctis M, Di Iaconi C, Lopez A, Rossetti S (2010) Granular biomass structure and population dynamics in a sequencing batch biofilter granular reactor (SBBGR). Bioresour Technol 101:2152-2158

Falletti L, Conte L (2007) Upgrading of activated sludge wastewater treatment plants with hybrid moving-bed biofilm reactors. Ind Eng Chem Res 46:6656-6660

Ferrai M, Guglielmi G, Andreottola G (2010) Modelling respirometric tests for the assessment of kinetic and stoichiometric parameters on MBBR biofilm for municipal wastewater treatment. Environ Modell Softw 25:626-632

Germain E, Stephenson T, Pearce P (2005) Biomass characteristics and membrane aeration: toward a better understanding of membrane fouling in submerged membrane bioreactors (MBRs). Biotechnol Bioeng 90(3):316-322

Germain E, Bancroft L, Dawson A, Hinrichs C, Fricker L, Pearce P (2007) Evaluation of hybrid processes for nitrification by comparing MBBR/AS and IFAS configurations. Water Sci Technol 55(8-9):43-49

Gomez M, Dvorak L, Ruzickova I, Holba M, Wanner J (2012) Operational experience with a seasonally operated full-scale membrane bioreactor plant. Bioresour Technol 121:241-247

Gómez-Silván C, Molina-Muñoz M, Poyatos JM, Ramos A, Hontoria E, Rodelas B, González-López J (2010) Structure of archaeal communities in membrane-bioreactor and submerged-biofilter wastewater treatment plants. Bioresour Technol 101:2096-2105

Helle S (1999) A respirometric investigation of the activated sludge treatment of BKME during steady state and transient operating conditions. Ph.D. thesis, University of British Columbia

Henze M, Gujer W, Mino T, Van Loosdrecht MCM (2000) Activated sludge models ASM1, ASM2, ASM2d and ASM3. IWA Publishing, London

Ivanovic I, Leiknes T (2008) Impact of aeration rates on particle colloidal fraction in the biofilm membrane bioreactor (BFMBR). Desalination 231:182-190

Ivanovic I, Leiknes T, Ødegaard H (2008) Fouling control by reduction of submicron particles in a BF-MBR with an integrated flocculation zone in the membrane reactor. Separ Sci Technol 43:1871-1883 
Judd S (2010) The MBR book. Principles and applications of membrane bioreactors for water and wastewater treatment. Oxford, Butterworth Heinemann

Kermani M, Bina B, Movahedian H, Amin MM, Nikaein M (2008) Application of moving bed biofilm process for biological organics and nutrients removal from municipal wastewater. Am J Environ Sci 4:675-682

Kim H, Gellner J, Boltz J, Freudenberg R, Gunsch C (2010) Effects of integrated fixed film activated sludge media on activated sludge settling in biological nutrient removal systems. Water Res 4(4):1553-1561

Krzeminski P, Iglesias-Obelleiro A, Madebo G, Garrido JM, VanderGraaf JHJM, VanLier JB (2012) Impact of temperature on raw wastewater composition and activated sludge filterability in full-scale MBR systems for municipal sewage treatment. J Membr Sci 423-424:348-361

Leiknes L, Ødegaard H (2007) The development of a biofilm membrane bioreactor. Desalination 202:135-143

Lepš J, Šmilauer P (1999) Multivariate Analysis of Ecological Data. University of South Bohemia, Ceské Budejovice, Faculty of Biological Sciences

Mannina G, Viviani G (2009) Hybrid moving bed biofilm reactors: an effective solution for upgrading a large wastewater treatment plant. Water Sci Technol 60:1103-1116

Martín-Pascual J, López-López C, Cerdá A, González-López J, Hontoria E, Poyatos JM (2012) Comparative kinetic study of carrier type in a moving bed system applied to organic matter removal in urban wastewater treatment. Water Air Soil Poll 223:1699-1712

Melin E, Leiknes T, Helness H, Rasmussen V, Ødergard H (2005) Effect of organic loading rate on a wastewater treatment process combining moving bed biofilm and membrane reactors. Water Sci Technol 51:421-430

Najafpour G, Yieng HA, Younesi H, Zinatizadeh A (2005) Effect of organic loading on performance of rotating biological contactors using palm oil mill effluents. Process Biochem 40:2879-2884

Ødegaard H, Rusten B, Westrum T (1994) A new moving bed biofilm reactor-applications and results. Water Sci Technol 29:157-165

Plattes M, Henry E, Schosseler PM, Weidenhaupt A (2006) Modelling and dynamic simulation of a moving bed bioreactor for the treatment of municipal wastewater. Biochem Eng J 32:61-68

Plattes M, Henry E, Schosseler PM (2008) A zero-dimensional biofilm model for dynamic simulation of moving bed bioreactor systems: model concepts, peterson matrix, and application to a pilot-scale plant. Biochem Eng J 40:392-398

Poyatos JM, Molina-Muñoz M, Delgado F, González-López J, Hontoria E (2008) Flux influence on membrane fouling in a membrane bioreactor system under real conditions with urban wastewater. J Environ Sci Health A Tox Hazard Subst Environ Eng 43:1685-1691

Rahimi Y, Torabian A, Mehrdadi N, Habibi-Rezaie M, Pezeshk H, Nabi-Bidhendi G (2011) Optimizing aeration rates for minimizing membrane fouling and its effect on sludge characteristics in a moving bed membrane bioreactor. J Hazard Mater 186: 1097-1102

Rodríguez FA, Poyatos JM, Reboleiro-Rivas P, Osorio F, GonzálezLópez J, Hontoria E (2011) Kinetic study and oxygen transfer efficiency evaluation using respirometric methods in a submerged membrane bioreactor using pure oxygen to supply the aerobic conditions. Bioresour Technol 102:6013-6018

Rodríguez FA, Reboleiro-Rivas P, Osorio F, Martínez-Toledo MV, Hontoria E, Poyatos JM (2012) Influence of mixed liquid suspended solids and hydraulic retention time on oxygen transfer efficiency and viscosity in a submerged membrane bioreactor using pure oxygen to supply aerobic conditions. Biochem Eng J 60:135-141
Ruiz LM, Arévalo J, Parada J, González D, Moreno B, Pérez J, Gómez MA (2011) Respirometric assays of two different MBR (microfiltration and ultrafiltration) to obtain kinetic and stoichiometric parameters. Water Sci Technol 63:2478-2485

Rusten B, Eikebrokk B, Ulgenes Y, Lygren E (2006) Design and operations of the kaldnes moving bed biofilm reactors. Aquacult Eng 34:322-331

Rutt K, Seda J, Johnson CH (2006) Two year case study of integrated fixed film activated sludge (IFAS) at Broomfield, CO WWTP. Proceedings of the water environment federation 225-239

Sokół W, Ambaw A, Woldeyes B (2009) Biological wastewater treatment in the inverse fluidised bed reactor. Chem Eng J 150:63-68

Sriwiriyarat T, Randall CW (2005) Performance of IFAS wastewater treatment processes for biological phosphorus removal. Water Res 39(16):3873-3884

Trapani DD, Mannina G, Torregrossa M, Viviani G (2010) Quantification of kinetic parameters for heterotrophic bacteria via respirometry in a hybrid reactor. Water Sci Technol 61:1757-1766

Trapani DD, Capodici P, Cosenza A, Di Bella G, Mannina G, Torregrossa M, Viviani G (2011) Evaluation of biomass activity and wastewater characterization in a UCT-MBR pilot plant by means of respirometric techniques. Desalination 269:190-197

Van der Roest HF, Lawrence DP, Van Bentem AGN (2002) Membrane Bioreactors for Municipal Wastewater Treatment. IWAI Publishing, Cornwall

Wang XM, Wang JL (2012) Denitrification of nitrate-contaminated groundwater using biodegradable snack ware as carbon source under low-temperature condition. Int $\mathrm{J}$ Environ Sci Technol 9:114-118

Wang R, Wen X, Qian Y (2005) Influence of carrier concentration on the performance and microbial characteristics of a suspended carrier biofilm reactor. Process Biochem 4:2992-3001

Yang Y, Yang F (2011) Nitrogen removal via short-cut simultaneous nitrification and denitrification in an intermittently aerated moving bed membrane bioreactor. J Hazard Mater 195:318-323

Yang S, Yang F, Fu Z, Lei R (2009) Comparison between a moving bed membrane bioreactor and a conventional membrane bioreactor on organic carbon and nitrogen removal. Bioresource Technol 100:2369-2374

Yang S, Yang F, Fu Z, Wang T, Lei R (2010) Simultaneous nitrogen and phosphorus removal by a novel sequencing batch moving bed membrane bioreactor for wastewater treatment. J Hazard Mater 175:551-557

Zekker I, Rikmann E, Tenno T, Menert A, Lemmiksoo V, Saluste A, Tenno T, Tomingas M (2011) Modification of nitrifying biofilm into nitritating one by combination of increased free ammonia concentrations, lowered HRT and dissolved oxygen concentration. J Environ Sci 23(7):1113-1121

Zekker I, Rikmann E, Tenno T, Lemmiksoo V, Menert A, Loorits L, Vabamäe P, Tomingas M, Tenno T (2012a) Anammox enrichment from reject water on blank biofilm carriers and carriers containing nitrifying biomass: operation of two moving bed biofilm reactors (MBBR). Biodegradation 23(4):547-560

Zekker I, Rikmann E, Tenno T, Saluste A, Tomingas M, Menert A, Loorits L, Lemmiksoo V, Tenno T (2012b) Achieving nitritation and anammox enrichment in single moving-bed biofilm reactor treating reject water. Environ Technol 33(6):703-710

Zekker I, Rikmann E, Tenno T, Vabamäe P, Kroon K, Loorits L, Saluste A, Tenno T (2012c) Effect of concentration on anammox nitrogen removal rate in a moving bed biofilm reactor. Environ Technol 33(20):2263-2271

Ziolko D, Hala D, Lester JN, Scrimshaw MD (2009) The effectiveness of conventional trickling filter treatment plants at reducing concentrations of copper in wastewaters. Sci Total Environ 407:6235-6241 